\title{
A teoria da recepção e a historicidade da compreensão das Escrituras
}

\author{
José Adriano Filho*
}

\section{Resumo}

A historicidade de compreensão das Escrituras e de seus leitores, uma proposição básica da teoria da recepção bíblica, significa que um agente tem que tornar o significado do texto concreto. Como nossa pertença à história não nos permite pensar num conhecimento imparcial garantido pela aplicação de um método e nossa localização numa situação histórica específica possibilita a abertura aos legados culturais que nos precedem, a história da recepção de um texto bíblico deve ser considerada como um relato das instâncias históricas concretas da sua apropriação e impacto no mundo da vida dos seus leitores. A teoria da recepção bíblica deve ser considerada como um relato das instâncias históricas concretas da sua apropriação e impacto no mundo da vida dos seus leitores. Ela privilegia as condições de leitura do texto pelos seus leitores e leitoras, não a reconstrução de como a obra foi produzida, isto é, não procura determinar o significado original do texto pretendido pelo autor, mas demonstrar como o seu significado se desdobra historicamente.

Palavras-chave: Teoria da Recepção. Historicidade da Compreensão. Escrituras.

\section{Reception theory and the historicity of understanding the Scriptures}

\section{Abstract}

The historicity of understanding of Scripture and its readers, a basic proposition of biblical reception theory, means that an agent has to make the meaning of the text concrete. As our belonging to history does not allow us to think of impartial knowledge guaranteed by the application of a method and our location in a specific historical situation allows us to open up to the cultural legacies that precede us, the history of

* Doutor em Ciências da Religião (UMESP) e em Teoria e História e Teoria Literária (UNICAMP), é professor na Faculdade Unida de Vitória, ES. http://orcid.org/00000002-8157-4529. E-mail: joseadriano@fuv.edu.br . 
the reception of a biblical text must be considered as an account of concrete historical instances of its appropriation and impact on the world of life of its readers. Biblical reception theory must be considered as an account of the concrete historical instances of its appropriation and impact on the lifeworld of its readers. It privileges the reading conditions of the text by its readers and readers, not the reconstruction of how the work was produced, that is, it does not seek to determine the original meaning of the text intended by the author, but to demonstrate how its meaning unfolds historically.

Keywords: Reception Theory. Historicity of Understanding. Scriptures.

\section{La teoría de la recepción y la historicidad de la comprensión de las Escrituras}

\section{Resumen}

La historicidad de la comprensión de las Escrituras y sus lectores, una proposición básica de la teoría de la recepción bíblica, significa que un agente tiene que concretar el significado del texto. Como nuestra pertenencia a la historia no nos permite pensar en un conocimiento imparcial garantizado por la aplicación de un método y nuestra ubicación en una situación histórica concreta nos permite abrirnos a los legados culturales que nos preceden, la historia de la recepción de una obra bíblica debe ser considerada como un relato de instancias históricas concretas de su apropiación e impacto en el mundo de la vida de sus lectores. La teoría de la recepción bíblica debe considerarse como un relato de los casos históricos concretos de su apropiación e impacto en el mundo de la vida de sus lectores y privilegia las condiciones de lectura del texto por parte de sus lectores y lectores, no la reconstrucción de cómo se produjo la obra, es decir, no busca determinar el significado original del texto pretendido por el autor, sino demostrar cómo su significado. se desarrolla históricamente.

Palabras-clave: Teoría de la recepción. Historicidad del entendimiento. Escrituras.

"Quando lemos, nossa expectativa é função do que já lemos - não somente no texto que lemos, mas em outros textos -, e os acontecimentos imprevistos que encontramos no decorrer de nossa leitura obriga-nos a reformular nossas expectativas e a reinterpretar o que já lemos, tudo o que já lemos até aqui neste texto e em outros. A leitura procede, pois, em duas direções ao mesmo tempo, para a frente e para trás, sendo que um critério de coerência existe desde o princípio da pesquisa do sentido e das revisões contínuas pelas quais a leitura garante uma significação totalizante à nossa experiência" (COMPAGNON, 2006, p. 148-149).

\section{A estética da recepção}

Quando Hans Robert Jauss proferiu a Aula Inaugural de sua cátedra na Universidade de Constança, em 1967, a abordagem histórica dos estudos literários havia caído em total descrédito. Naquela época, as sucessivas correntes formalistas, que viam o texto com um fim em si mesmo e isolavam- 
no do seu produtor, do seu destinatário e do contexto de ambos, tinham alcançado sua expressão última com o estruturalismo francês. A ideia de que nem o autor nem o meio sócio-histórico têm peso na análise científica de uma obra literária transformou-a num exemplo de escrita sem qualquer vínculo com o seu mundo histórico. O texto literário, convertido em artefato verbal autossuficiente, tornou-se objeto de escrutínio, exposto ao desdobramento de seus dispositivos internos, dos mecanismos que compunham sua estrutura operacional. Jauss, que em 1963 participou da formação do grupo de pesquisa interdisciplinar "Poetik und Hermeneutik" (1963-1994), que buscava repensar as condições para o estudo da arte e da literatura a partir da dinâmica e diálogo entre diversas perspectivas, não aceitava as limitações que o estruturalismo e o marxismo impunham à Ciência da Literatura, ou seja, a interpretação dos textos literários e sua relação com a história e a experiência de recepção concreta dos seus leitores ${ }^{1}$.

O título da Aula Inaugural de Jauss: "A história da literatura como provocação à ciência da literatura" ("Literaturgeschichte als Provokation der Literaturwissenschaft"), apelava à desvalida história literária para desafiar o formalismo imanentista então vigente. Na verdade, o título original da Aula Inaugural "O que é e com que finalidade se estuda a história da literatura?" ("Was heisst und zu welchem Ende studiert man Literaturgeschichte?"), publicada no mesmo ano com o título hoje conhecido e, posteriormente, incluída no volume "A história da literatura como provocação à ciência da literatura" (1970), é uma paráfrase da Aula Inaugural de Friedrich Schiller na Universidade de Jena, em 1789: “O que é e com que propósito se estuda a história universal?" ("Wass heisst und zu welchem Ende studiert man Universalgeschichte?"), que reivindicava uma nova abordagem da história e da

Hans Robert Jauss rejeita a ideia marxista do papel da produção na obra de arte, que considera secundários a recepção e os efeitos literários do texto para os leitores. A literatura era reduzida à apropriação humana da natureza e o controle do processo econômico refletia apenas o que já era conhecido dentro do horizonte social e histórico. Ele questiona também a tese de que a literatura podia servir a uma função revolucionária, se se pode reconhecer apenas "as imagens estabilizadas e pré-conceitos de sua situação histórica", mas não permitir a revelação de que a literatura possa criar perspectivas novas no mundo. Quanto ao Formalismo, que acentua o caráter artístico da literatura, vendo-a como objeto autônomo de investigação, Jauss afirma que a teoria do método formalista "alçou novamente a literatura à condição de um objeto autônomo de investigação, na medida em que desvinculou a obra literária de todas as condicionantes históricas e, à maneira da nova linguística estrutural, definiu em termos puramente funcionais a sua realização específica, como a soma de todos os procedimentos artísticos nela empregados" (JAUSS, 1994, p. 18). 
literatura porque as respostas às perguntas feitas pelo paradigma humanista, que se desenvolveu durante o Renascimento e forneceu as diretrizes tomadas dos textos clássicos como normas para avaliar as demais obras da literatura, não eram mais satisfatórias. Schiller percebeu que, com o surgimento do historicismo, a literatura clássica não poderia mais ser considerada como algo que incorporava normas atemporais. Ele explicou por que a sua geração enfrentava uma crise nos estudos literários e estabeleceu as expectativas da história literária do século XIX. Jauss, ao modificar o título da conferência de Schiller e inserir a palavra "literária" no lugar de "universal", evoca o seu predecessor e indica a necessidade de restaurar a dimensão histórica dos estudos literários, estabelecendo vínculos com os documentos do passado a partir das inquietações do presente (HOLUB, 1984, p. 53-54).

A "história da literatura" é considerada uma provocação, um desafio que estimulava o desenvolvimento de uma ciência ou teoria da literatura. Jauss combina as contribuições das correntes formalistas com uma perspectiva histórica que, na prática, pressupõe a reintrodução das figuras do leitor e do público - dos sucessivos públicos historicamente determináveis - na análise da dinâmica dos fatos literários. Ele apresenta os fundamentos de uma nova história da literatura - que aspirava a configurar-se como ciência da literatura, cujos protagonistas seriam o autor, o texto e o público como fator criativo, mas é importante destacar há antecedentes que desde o início da década de 1960 apontavam para o papel de receptor ${ }^{2}$. A indicação de que uma mudança nas normas do que se considera literário ou no gosto hegemônico produz uma recepção distinta dos textos literários levou Jauss a postular uma história da literatura que atendesse à recepção, isto é, ao sentido e função concedido às obras literárias em cada momento histórico.

A novidade da abordagem de Jauss é a indicação da importância do leitor no processo de interpretação da obra literária. W. Krauss havia advertido

2 A reivindicação do receptor era parte do espírito de época, que perguntava pelo adiado ou proibido, o corpo contra o espírito, o jogo contra a função, a transgressão contra a escravidão. Em 1968, Roland Barthes havia proclamado "a morte do autor", afirmando que só o leitor dá unidade à multiplicidade de citações que constituem a urdidura da escrita. Julio Cortázar dedicou o seu romance O jogo da amarelinha (1963) ao "leitor ativo" como parceiro no processo de construção ou montagem da obra. Umberto Eco, em Obra aberta (1962), apresenta uma definição um novo tipo de poética, em que o intérprete se torna coparticipe da obra, interferindo na sua forma final, e a definição de uma poética que, mesmo conservando a forma final da obra como acabada e imutável, admite, ainda assim, uma pluralidade de significados, a depender da abordagem do intérprete (RÓDENAS DE MOYA, 2013, p. 12-13). 
que "a obra literária não é escrita no vazio, nem dirigida à posteridade: é escrita sim para um destinatário concreto". Nesse contexto, as contribuições de J. Mukarovsky, F. Wodicka e R. Ingarden são também importantes para a teoria recepção. Para Mukarovsky, "o objeto imediato de valoração estética não é o artefato 'material', mas sim o 'objeto estético, que apresenta seu reflexo na consciência do observador"”. Wodicka afirma que a "obra é um signo estético dirigido ao leitor, o que exige a reconstituição histórica da sensibilidade do público para entender-se como ela se concretiza" (COSTA LIMA, 2002, p. 15, 17). Ingarden afirma que o exame do modo de ser da obra literária indica que ela é "uma estrutura linguístico-imaginária, permeada de pontos de indeterminação e de esquemas potenciais de impressões sensoriais, os quais, no ato de criação ou da leitura, são preenchidos e atualizados, transformando o que era trabalho artístico do criador em objeto estético do leitor" (INGARDEN, 1965; BORDINI \& AGUIAR, 1988, p. 82).

O livro de Hans-Georg Gadamer, Verdade e Método (1960) é também importante para Jauss, que se interessou pela historicidade que Gadamer considerou essencial em qualquer texto e a historicidade de qualquer ato receptivo, que transformava a leitura numa convergência de historicidade, ou fusão de horizontes, da qual emerge o significado ${ }^{3}$. Jauss assimila as ideias de Gadamer, entre as quais a ideia de que a compreensão se organiza de forma dialógica mediante o encontro dos horizontes do texto, que interroga o leitor, e o leitor, que responde à pergunta que o texto formula. Para ele, a produção

3 "Gadamer's philosophical hermeneutics offers new insights into the nature of understanding. (...) it characterises understanding as an event, that is, understanding happens, and it happens in history and in language. Most importantly, for Gadamer, understanding is not just another human activity, but the fundamental mode of beingin-the-world. This amounts to a radical paradigm change, which runs against objectivist theories privileging the application of method considered to be the only valid access to truth. The concept of method is based by and large on the subject-object epistemological model whereby the subject applies a method in an unproblematic way to the object of inquiry in order to obtain its truth. Put differently, reality can be turned into an object of inquiry to be grasped by a presumably detached subject. To be sure, Gadamer is reluctant to equate truth with methodological results. In this hermeneutic paradigm, understanding as the primary way of our-being-in-the-world is by necessity the a priori condition for any scientific activity. Hermeneutics, in his view, provides the Geisteswissenschaften [humanities] with a unique foundation on the grounds of its universal status vis-a-vis the epistemological model of the natural sciences. Gadamer argues that the finitude of the inquirer and the infinite nature of the Sache [subject-matter] pose serious limits to what can be known methodologically. In that sense, truth will never be grasped once and for all by means of any method" (MORALES VÁSQUEZ, 2012, p. 18). 
e difusão da obra literária devem ser abordados junto com o estudo de sua recepção e seus efeitos nos leitores. Autor, obra e público eram fatores de um sistema de comunicação dinâmico dependente do desenvolvimento histórico. Os leitores, na medida em que utilizam o texto para entendê-lo e alcançar o prazer estético, tornam-se agentes criativos, tornando-se os verdadeiros motores da história literária. As sucessivas leituras diacrônicas formam uma tradição de recepções que o historiador deve levar em conta e que mudam de acordo com os horizontes de expectativa dos sucessivos públicos.

O conceito de "horizonte de expectativas" se refere ao conjunto de ideias - valores morais, convenções, normas estéticas, regularidades formais - que tornam os leitores agentes ativos durante a recepção, permitindo-lhes interpretar a obra, ou seja, saber que pergunta ela procurava responder. Esse horizonte é historicamente variável e corresponde a um público específico, ou a uma "comunidade interpretativa" (FISH, 1980), então é preciso recriar a questão colocada pelo texto para reconstruir o horizonte de expectativas. Quando a novidade de uma obra se afasta do estabelecido e não é compreendida a partir do sistema dominante de ideias, ocorre uma ruptura no horizonte de expectativas, que não é apenas estética, mas também histórica. Essas rupturas ou descontinuidades respondem a diferentes modos de recepção que o historiador pode analisar para explicar a natureza de tais mudanças. A metáfora "horizonte de expectativas" funciona tanto para o público de uma determinada sociedade e época quanto para explicar o mecanismo de progressão informativa do próprio texto, a forma como a obra cria no leitor pressupostos que se confirmam ou não na medida em que a leitura avança e permite a construção do sentido.

Dez anos após a sua Aula Inaugural de 1967, Jauss reconhece que a dedução de um horizonte contextual de expectativas apresenta muitas dificuldades frente à análise mais eficaz do horizonte interno, gerado pelo próprio sistema semiótico, que é o texto. O texto surge como um dispositivo cujas estruturas geram sentido potencialmente, mas somente o leitor, ao se atualizar no ato de recepção e interpretação, concretiza esse sentido a partir de suas próprias circunstâncias. A práxis vital do leitor condiciona o que se busca e se extrai da obra, determina o sentido de sua interpretação e esta, por sua vez, se torna um acontecimento histórico que se soma à "tradição interpretativa". Dessa forma, a mudança de paradigma que ele defende supõe o reconhecimento da condição histórica inquestionável dos discursos culturais e, sobretudo, dos textos literários, e sanciona a abordagem 
semiótica da obra como um método plausível de análise de suas codificações internas. Sua hermenêutica exige uma tarefa de investigação sócio-histórica que visa construir os diversos sistemas culturais dentro dos quais os atos interpretativos concretos acontecem em cada momento histórico - e em cada espaço geográfico que implicava uma mudança de sistema - ou, para dizê-lo com a linguagem de Iuri Lotman, é preciso reconstruir as diferentes semiosferas em que as obras foram produzidas, divulgadas e recebidas (RÓDENAS DE MOYA, 2013, p. 14-15; NOGUEIRA, 2012, p. 20-24).

O programa de Jauss exigia o exame do sistema de signos da obra, para o qual já não bastava o exame de suas estruturas linguísticas ou retóricas, mas era fundamental explorar os processos cognitivos que intervêm na recepção. Essa tarefa foi realizada por seu colega da Universidade de Constança, Wolfgang Iser, cujo interesse estava na questão de "como" e "em que condições" um texto tem significado para o leitor. Em diversas obras: Die Appellstruktur der Texte [1970], Der implizite Leser [O leitor implícito],1972), Der Akt des Lesens [O ato da leitura], 1976), Iser procura apresentar o significado como resultado da interação entre o texto e o leitor, como um "objeto a ser experimentado", não como um objeto a ser definido. Ele distingue duas modalidades de interação entre a obra e o leitor: o efeito que toda obra provoca em seu leitor e a recepção, processo histórico que acontece a partir das diferentes interpretações que cada leitor lhe impõe. Acreditando que os signos passíveis de leitura estão abertos a múltiplas interpretações, pois não são concebidos como um espelho da realidade, convoca o leitor a participar do processo de criação deles. Esta participação não se limita ao mero preenchimento dos vazios que toda obra traz consigo, mas é o processo de constituição da própria obra que, graças à atuação do leitor, passa de "mero artefato artístico a objeto estético, passível de contemplação, entendimento e interpretação" (ZILBERMAN, 2001, p. 51).

Jauss não percorreu o caminho adotado por Iser, pois estava mais interessado em como a experiência estética é realizada no sujeito e como ela desempenha a função de gerar normas de assentimento ou dissidência social. A essas questões, Jauss dedicou sua obra Experiência estética e hermenêutica literária ("Ästhetische Erfahrung und literarische Hermeneutik", 1977). Jauss havia considerado que o valor estético de uma obra literária poderia ser determinado pela distância entre o horizonte de expectativas do público e aquele postulado pela obra literária, ou seja, a distância entre o sistema de normas e convenções assimiladas pelo público como uma expectativa padrão 
e o rompimento desse horizonte pela obra. Quanto maior o desvio, maior o mérito artístico. Avaliar essa distância exigia a reconstrução do horizonte de expectativa contextual, que ainda era uma árdua tarefa da arqueologia interpretativa. Assim, a descontinuidade dentro de um sistema de normas ou a frustração da expectativa do público tornou-se um critério de valor estético e uma força de mudança na história literária.

Em 1977, Jauss altera essa concepção, pois a arte nem sempre nega ou questiona a sociedade em que nasceu, nem sempre viola o sistema normativo e de predição que opera em seu público. A razão por esta mudança está ligada a uma desvalorização do que se refere como "estética da negatividade", desenvolvida por Theodoro Adorno, na sua Teoria Estética (1970). O que incomodava Jauss na teoria de Adorno é que ela atribui uma função social positiva para a arte somente quando a obra de arte nega a sociedade específica em que é produzida. Ela, consequentemente, não deixa espaço para uma função afirmativa e progressiva da literatura, uma vez que a literatura em geral se define por sua oposição às práticas sociais, por seu caráter ascético (JAUSS, 1982, p. 13-21; HOLUB, 1984, p. 70-73). Jauss, então, incorpora em sua estética um fator que Adorno subestimou e que constitui a função primária da arte: a produção do prazer estético, distinguindo três momentos na experiência estética, o primeiro, poiesis, relacionado à produção do texto, o segundo aisthesis, relacionado com a recepção que, ao exigir um conhecimento das estruturas da realidade compartilhada, fortalece os laços de unidade da comunidade, o terceiro, catharsis, no qual o fator comunicativo predomina e ativa a interação emocional e intelectual do indivíduo, que inevitavelmente carrega um componente moral, que nada tem a ver com as prescritivas morais, mas com uma moralidade exploratória, própria da arte, na qual o sujeito é o responsável pela tomada de decisão (JAUSS, 1982, p. 46-111).

\section{A "provocação" de Hans Robert Jauss}

A Aula Inaugural de Jauss "A história da literatura como provocação à ciência da literatura" representa não somente como desafio à inadequação das teorias literárias da sua época, mas também propõe um novo paradigma para os estudos literários. A sua proposta, que é apresentada em sete teses, constituem a segunda parte da obra $A$ bistória da literatura como provocação à ciência da literatura: 
Tese 1: "Uma renovação da história da literatura demanda que se ponham abaixo os preconceitos do objetivismo histórico e que se fundamentem as estéticas tradicionais da produção e da representação numa estética da recepção e do efeito. A historicidade da literatura não repousa numa conexão de 'fatos literários' estabelecida post festum, mas no experienciar dinâmico da obra literária por parte de seus leitores. Essa mesma relação dialógica constitui o pressuposto também da história da literatura. $\mathrm{E}$ isso porque, antes de ser capaz de compreender e classificar uma obra, o historiador da literatura tem sempre de novamente fazer-se, ele próprio, leitor. Em outras palavras: ele tem de ser capaz de fundamentar seu próprio juízo tomando em conta sua posição presente na série histórica dos leitores".

A história literária não se baseia primariamente nos fatos, mas na experiência estética do texto pelos leitores: "A obra literária não é um objeto que exista por si só, oferecendo a cada observador em cada época um mesmo aspecto. (...) Ela é, antes, como uma partitura voltada para a ressonância sempre renovada da leitura, libertando o texto da matéria das palavras e conferindo-lhe existência atual" (JAUSS, 1994, p. 25). A história literária é processo contínuo de recepção estética. Os textos não são como os eventos históricos, mas se tornam evento quando o leitor os lê à luz de outras obras literárias que moldam sua recepção de obras futuras. Na recepção, na interrelação entre a obra literária e o público leitor, ela revela sua estrutura sentido (PARRIS, 2009, p. 129).

Tese 2: "A análise da experiência literária do leitor escapa ao psicologismo que a ameaça quando descreve a recepção e o efeito de uma obra a partir do sistema de referências que se pode construir em função das expectativas que, no momento histórico do aparecimento de cada obra, resultam do conhecimento prévio do gênero, da forma e da temática de obras já conhecidas, bem como da oposição entre a linguagem poética e a linguagem prática".

Um texto não surge no vazio, mas utiliza sinais, gêneros e outros traços familiares aos leitores. O evento da experiência estética não é uma experiência subjetiva arbitrária. Há um horizonte intersubjetivo que determina os efeitos ou influências de um texto. Como os textos empregam convenções herdadas de outros textos pelo leitor e que se tornam parte das formas de vida ou do (s) jogo (s) de linguagem do leitor, o efeito do texto não é um evento privado, mas de caráter intersubjetivo. As expectativas que o leitor traz para 
o texto são herdadas de sua tradição e das regras que ele aprendeu ao ler outros textos. Essas expectativas são "então variadas, corrigidas, alteradas ou mesmo apenas reproduzidas" à medida que ele lê o texto (JAUSS, 1994, p. 28-29), resultando numa expansão semiótica e correção do sistema do leitor. Os diversos horizontes de expectativa, seja o horizonte em que a obra apareceu pela primeira vez ou os horizontes sucessivos nos quais ela é lida, são intersubjetivos e, portanto, abertos à investigação. Quando estudamos os gêneros familiares ao autor e aos leitores originais, podemos determinar se o autor escrevia de uma forma com a qual os leitores originais estavam familiarizados ou era inovador na forma como estruturava o texto (PARRIS, 2009, p. 130-131).

Tese 3: "O horizonte de expectativa de uma obra, que assim se pode reconstruir, torna possível determinar seu caráter artístico a partir do modo e do grau segundo o qual ela produz seu efeito sobre um suposto público. Denominando-se distância estética aquela que medeia entre o horizonte de expectativa preexistente e a aparição de uma obra nova - cuja acolhida, dando-se por intermédio da negação de experiências conhecidas ou da conscientização de outras, jamais expressas, pode ter por consequência uma "mudança de horizonte"-, tal distância estética deixa-se objetivar historicamente no espectro das reações do público e do juízo da crítica (sucesso espontâneo, rejeição ou choque, casos isolados de aprovação, compreensão gradual ou tardia)".

As possibilidades de diálogo com a obra dependem do grau de identificação ou de distanciamento do leitor com ela, naquilo que diz respeito às convenções sociais e culturais a que está vinculado e à consciência que delas possui. Se uma obra está alinhada com o horizonte de expectativas do leitor, não há mudança de horizonte. Jauss classifica este tipo de obra como "arte culinária", pelo fato de "não exigir nenhuma mudança de horizonte, mas sim de simplesmente atender a expectativas que delineiam uma tendência dominante do gosto, na medida em que satisfaz a demanda pela reprodução do belo usual, confirma sentimentos familiares, sanciona as fantasias do desejo, torna palatáveis - na condição de "sensação" - as experiências não corriqueiras ou mesmo lança problemas morais, mas apenas para "solucionálos" no sentido edificante, qual questões já previamente decididas" (JAUSS, 1994, p. 31-32). Se não experimentamos a provocação, a negação ou o estímulo da obra de arte, não há experiência. Sem esta provocação, nunca 
aprenderemos a reconhecer o que não conhecemos, a fazer perguntas, amadurecer e desenvolver como indivíduos, comunidade e tradições. Ao mesmo tempo, a tradição tem um poder nivelador, ou homogeneizador, ou mesmo as obras mais inovadoras e provocativas. A distância estética entre o texto e a audiência original diminui para os leitores posteriores "quando a negatividade original da obra houver se transformado em obviedade e, daí em diante, adentrado ela própria, na qualidade de uma expectativa familiar, o horizonte da experiência estética futura" (JAUSS, 1994, p. 32).

Tese 4: "A reconstrução do horizonte de expectativa sob o qual uma obra foi criada e recebida no passado possibilita, por outro lado, que se apresentem as questões para as quais o texto constituiu uma resposta e que se descortine, assim, a maneira pela qual o leitor de outrora terá encarado e compreendido a obra. Tal abordagem corrige as normas de uma compreensão clássica ou modernizante da arte - em geral aplicadas inconscientemente - e evita o círculo vicioso do recurso a um genérico espírito da época. Além disso, traz à luz a diferença hermenêutica entre a compreensão passada e apresente de uma obra, dá a conhecer a história de sua recepção [...] e coloca em questão, como um dogma platonizante da metafisica filológica, a aparente obviedade segundo a qual a poesia encontra-se atemporalmente presente no texto literário, e seu significado objetivo, cunhado de forma definitiva, eterna e imediatamente acessível ao intérprete".

Compreendemos um texto quando tivermos compreendido a questão para a qual ele é uma resposta. A questão reconstruída nunca é idêntica à questão original que o texto procura responder, porque qualquer reconstrução de um horizonte passado está sempre envolvida no horizonte presente do intérprete. A história da recepção de um texto é resultado do desdobrar do significado potencial do texto, que não encontra apenas no horizonte original, mas deriva igualmente do horizonte do intérprete. Não existe um significado "atemporalmente verdadeiro" para um texto disponível para o leitor. O significado surge da interação do texto com gerações sucessivas de leitores ${ }^{4}$. É preciso colocar em jogo os dois horizontes, o que resulta em um

$4 \quad$ "The meaning that a historically distant text can recapture for us does not emerge solely from the folds of the original horizon. It stems to an equal degree from the later horizon of experience belonging to the interpreter. Clearly the ongoing process of constituting meaning cannot be based on the mere negation of expectations revealed by a change in the horizon of experience. And by itself, the disappointment of an anticipation is not sufficient to reveal the folds of a possible meaning that remained unnoticed by the author 
processo contínuo de constituição do sentido de um texto. Para que ocorra a fusão de horizontes, o intérprete deve colocar a pergunta que possa tirar o texto "de volta do seu isolamento" para que ele possa nos responder e "dizer alguma coisa" (PARRIS, 2009, p. 140).

Tese 5: "A teoria estético-recepcional não permite somente apreender sentido e forma da obra literária no desdobramento histórico de sua compreensão. Ela demanda também que se insira a obra isolada em sua "série literária": a fim de que se conheça sua posição e significado histórico no contexto da experiência da literatura. No passo que conduz de uma história da recepção das obras à história da literatura, como acontecimento, esta última revela-se um processo no qual a recepção passiva de leitor e crítico transforma-se na recepção ativa e na nova produção do autor - ou, visto de outra perspectiva, um processo no qual a nova obra pode resolver problemas formais e morais legados pela anterior, podendo ainda propor novos problemas".

O conceito de evolução literária do Formalismo era unilateral e não explicava adequadamente o nascimento e desenvolvimento da literatura. A história literária não se preocupa apenas com uma séria cronológica de fatos literários, mas deve buscar as questões deixadas pelo texto e as soluções que o texto ofereceu às questões colocadas pelo seu autor. Para reconhecer estas questões, o intérprete precisa lançar mão de sua própria experiência, pois "as mudanças da série literária somente perfazem uma sequência histórica quando a oposição entre a forma velha e a nova dá a conhecer também a especificidade de sua mediação" (JAUSS, 1994, p. 43). As obras literárias oferecem soluções possíveis às questões colocadas pelos textos prévios e, também, apresentam novas questões. Isto significa que o "novo" não é meramente inovação, mas uma categoria histórica. Isto acontece quando um

and his contemporaries in the original horizon of a literary work. Since such folds can first be discovered only through the interpreter's later horizon, and can be expounded on only by assimilating them in a new interpretation, this horizon ought not simply be erased by aligning it with the earlier horizon when an anticipatory assumption proves unfounded. Instead, the content of the horizon of one's own experience must be brought into play, and mediated through the alien horizon in order to arrive at the new horizon of another interpretation. (...) This also means that 'while a right elucidation never understands the text better than the author understood it, it does surely understand it differently. Yet this difference must be of such a kind as to touch upon the Same toward which the elucidated text is thinking”" (JAUSS, 1989, p. 206-207). 
autor se reapropria intencionalmente do passado em sua obra ou oferece uma perspectiva inesperada ou nova sobre a literatura do passado: "O novo torna-se também categoria histórica quando se conduz a análise diacrônica da literatura até a questão acerca de quais são, efetivamente, os momentos históricos que fazem do novo em uma obra literária o novo; de em que medida esse novo é já perceptível no momento histórico de seu aparecimento; de que distância, caminho ou atalho a compreensão teve de percorrer para alcançar-lhe o conteúdo e, por fim, a questão de se o momento de sua atualização plena foi tão poderoso em seu efeito que logrou modificar a maneira de ver o velho e, assim, a canonização do passado literário” (JAUSS, 1994, 45).

Tese 6: "Os resultados obtidos pela linguística com a diferenciação e vinculação metodológica da análise diacrônica e da sincrónica ensejam, também no âmbito da história da literatura, a superação da contemplação diacrônica, até hoje a única habitualmente empregada. Se já a perspectiva histórico-recepcional depara constantemente com relações interdependentes a pressupor um nexo funcional [...] nas modificações da produção literária, então há de ser igualmente possível efetuar um corte sincrónico atravessando um momento do desenvolvimento, classificar a multiplicidade heterogênea de obras contemporâneas segundo estruturas equivalentes, opostas e hierárquicas e, assim, revelar um amplo sistema de relações na literatura de um determinado momento histórico. Poder-se-ia, então, desenvolver o princípio expositivo de uma nova história da literatura dispondo-se mais cortes no antes e no depois da diacronia, de tal forma que esses cortes articulem historicamente, em seus momentos constitutivos de épocas, a mudança estrutural na literatura".

O historiador da literatura precisa incorporar os estudos sincrônicos, "transversais" à sua obra, para captar as diferenças entre textos escritos no mesmo período, especialmente se há proximidade cultural entre eles. Os estudos sincrônicos nos permitem ver como os valores e estruturas concorrentes são realizados em diferentes textos que aparecem contemporâneos entre si durante tais mudanças. Isso nos permite formular alguma forma de estrutura heurística que nos permita examinar e explicar as perguntas feitas, as respostas recebidas e o significado das mudanças no sistema de relacionamento na literatura de um período histórico. A importância de uma obra se manifesta quando os resultados dos estudos diacrônicos e sincrônicos se sobrepõem. A mistura heterogênea de 
textos numa tradição ou horizonte literário está também sujeita ao poder nivelador da tradição, tal como o são as grandes obras. Aquilo que pode se assemelhar a um corpo de textos diversos e concorrentes no horizonte dos leitores originais combina-se num corpo coletivo de obras que moldam as expectativas, os valores e as preconcepções literárias das gerações seguintes. Os estudos sincrônicos nos ajudam a perceber que textos desempenharam um papel significativo na formação da tradição. As sucessivas seções transversais sincrônicas devem gerar pontos de intersecção com os estudos diacrônicos e, à medida em que esses pontos são encontrados, eles revelam a "evolução literária’, em suas cesuras entre uma época e outra - pontos estes, aliás, cuja escolha não é decidida nem pela estatística nem pela vontade subjetiva do historiador da literatura, mas pela história do efeito: por 'aquilo que resultou do acontecimento"” (JAUSS, 1994, p. 49). Os contornos de uma tradição literária são estabelecidos a partir das mudanças nos diferentes horizontes de expectativas (PARRIS, 2009, p. 142-144).

Tese 7: "A tarefa da história da literatura somente se cumpre quando a produção literária é não apenas apresentada sincrónica e diacronicamente na sucessão de seus sistemas, mas vista também como história particular, em sua relação própria com a história geral. Tal relação não se esgota no fato de podermos encontrar na literatura de todas as épocas um quadro tipificado, idealizado, satírico ou utópico da vida social. A função social somente se manifesta na plenitude de suas possibilidades quando a experiência literária do leitor adentra o horizonte de expectativa de sua vida prática pré-formando seu entendimento do mundo e, assim, retroagindo sobre seu comportamento social".

A história da interpretação de um texto é um elemento essencial para a sua compreensão. A função social da literatura ocorre quando a experiência literária do leitor entra no horizonte de expectativas de sua práxis vivida, realiza sua compreensão de mundo e tem também efeito em seu comportamento social: "A experiência da leitura logra libertá-lo das opressões e dos dilemas de sua práxis de vida, na medida em que o obriga a uma nova percepção das coisas. O horizonte de expectativa da literatura distingue-se daquele da práxis histórica pelo fato de não apenas conservar as experiências vividas, mas também antecipar possibilidades não concretizadas, expandir o espaço limitado do comportamento social rumo a novos desejos, pretensões e objetivos, abrindo, assim, novos caminhos para 
a experiência futura" (JAUSS, 1994, p. 52). A história literária deve também estudar sincronicamente as condições sociais e o pano de fundo que afetam as expectativas do autor e audiência. A "reserva de significado" do texto permite que ele se estenda além do horizonte original e desempenhe uma função socialmente formativa na vida de seus sucessivos leitores: “O abismo entre literatura e história, entre o conhecimento estético e o histórico, faz-se superável quando a história da literatura não se limita simplesmente a, mais uma vez, descrever o processo da história geral conforme esse processo se delineia em suas obras, mas quando, no curso da 'evolução literária', ela revela aquela função verdadeiramente constitutiva da sociedade que coube à literatura, concorrendo com as outras artes e forças sociais, na emancipação do homem de seus laços naturais, religiosos e sociais" (JAUSS, 1994, p. 57). A recepção é um processo que ocorre nas experiências e interpretações daqueles que "absorvem sua mensagem, apreciam-na ou julgam-na, reconhecem-na ou refutam-na, selecionam-na e esquecem-na, e em tal e extensão formam tradições, e aqueles que finalmente assumem um ativo papel respondendo a uma tradição e produzindo novas obras” (PARRIS, 2009, p. 145-146).

\section{A historicidade da compreensão das Escrituras}

A historicidade da compreensão das Escrituras e de seus leitores é uma proposição básica da teoria da recepção bíblica. Ela significa que um agente tem que tornar o significado do texto concreto e, nesse processo, um corpo de apropriações históricas dá origem às tradições que nos acompanham e moldam a nossa compreensão. Nesse sentido, a história da recepção do texto bíblico deve ser considerada como um relato das instâncias históricas concretas da sua apropriação e impacto no mundo da vida dos seus leitores. A hermenêutica histórica considera o texto como uma resposta à pergunta, antecipação ou preconcepção com que o intérprete a ele se dirige e, no momento de investigar o contexto original do texto, acaba reconstruindo com a forma da assimilação do horizonte próprio do intérprete, ou seja, o contexto é reconstruído de acordo com a forma da resposta que seus interesses predeterminam ${ }^{5}$. A hermenêutica literária não deve proceder desta

\footnotetext{
5 "A pesquisa bíblica histórico-crítica reconhece que o intérprete está ligado ao seu horizonte histórico, mas procura superar esta restrição ao 'colocar entre parêntesis' o horizonte do intérprete. O único a priori que ela reconhece é a lógica e os fatos ou dados empíricos que existem independentemente da observação e podem ser validados objetiva e subjetivamente. Ao observar objetivamente os fatos da história, sua meta é escapar da influência do seu horizonte histórico. Este ideal da objetividade histórica está presente, por exemplo, nas
} 
forma, pois a reconstrução historicista do horizonte de sentido do texto a partir da antecipação do intérprete é guiada pela sua preconcepção e, no final, ao construir o contexto de uma obra partindo do que se conhece a partir de outras disciplinas e segundo a pergunta que lhe é dirigida, faz-se o texto dizer o que implicitamente se espera saber.

Para superar a reconstrução histórica positivista e indicar a abertura de um outro horizonte, o texto não é mais lido como uma resposta, mas como o apelo a encontrar a questão para a qual a obra apresentava uma resposta (STIERLE, 1987, p. 87-144). Quando "o outro do texto não nos fala imediatamente", mas é considerado em sua própria alteridade, "pode-se evitar a mescla ingênua de horizontes', 'pode-se corrigir e ampliar a própria expectativa com a experiência do outro"” (JAUSS, 1989, p. 214). Segundo Jauss, Bakhtin concebeu de forma mais profunda a hermenêutica literária como uma teoria da compreensão mediada pela presença da alteridade (BAKHTIN, 2003). Sua hermenêutica dialógica assume o momento negativo da experiência estética, que implica a consciência dos elementos alheios ao sujeito na obra e, graças a ela, legitima a referência ao horizonte de sentido original. Uma vez aberto a este contexto, o leitor tende a recriar um mundo diferente daquele pressuposto pelo próprio horizonte. Esta reconstrução modifica o mundo fictício que poderia ser percebido ingenuamente na primeira leitura, prévia a qualquer indagação histórica. Neste sentido, é possível identificar-se com a experiência do outro; não se trata da experiência determinada que o autor teve a intenção de prescrever para a obra, mas uma experiência orientada pela alteridade da obra. Esse "compreender-se a si mesmo no outro" é, segundo Paul Ricoeur, "a abertura do discurso à experiência subjetiva do mundo". Aquilo que estava fechado na própria subjetividade e na do outro torna-se comunicável (JAUSS, 1989, p. 217; CAPDEVILA Y CASTELIS, 2005, p. 319-320).

Este é um dos aspectos que, stricto sensu, diferencia estruturalmente a experiência estética daquele tipo de experiência que os produtos culturais de consumo fácil e imediato buscam provocar. Este tipo de produtos procura evitar a experiência na qual o consumidor precisa sair de si mesmo, facilitando os recursos de identificação imediata e passiva. Entretanto, enquanto os

grandes séries de comentários que interpretam a Bíblia como um texto antigo, como uma relíquia do passado que está sujeita a uma análise técnica objetiva. Exige-se do intérprete a interpretação filológica, gramatical e histórica para a compreensão do texto, o que reduz a interpretação a uma forma de tradução" (ADRIANO FILHO, 2019, p. 317). 
produtos de consumo utilizam a ficção sem sair do mecanismo próprio da experiência cotidiana nem do contexto pressuposto, as obras de arte exigem sair do horizonte cotidiano e entrar no desconhecido. Em outras palavras, na identificação ingênua o sujeito se vê refletido a si mesmo no outro -, o qual supervaloriza, elogia ou caricatura alguns aspectos do receptor -, na identificação dialógica, "mais do que compreender-se a si mesmo no outro, há um momento de identificação do outro a partir da sua própria diferença" (CAPDEVILA Y CASTELIS, 2005, p. 320).

O caráter de horizonte aberto da experiência estética tem a forma de pergunta. Na abertura ao desconhecido o momento de identificação com o outro deve ter o caráter de aceitação da pergunta, do problema colocado pelo texto. A obra questiona o leitor sobre a sua situação inicial e lhe dirige uma pergunta. Mediante a recepção de uma obra chega-se a uma pergunta verdadeira, uma pergunta que dirigida a partir da alteridade e, não, como na compreensão ingênua de uma obra, uma pergunta dirigida a partir de si mesmo. Seria também ingênuo acreditar que se pode experimentar a situação do outro, colocando-se no seu lugar. A identificação com o outro é somente um passo da experiência estética, um momento do ir e vir dialético de si mesmo para o outro. Ao se colocar no outro horizonte a partir do qual uma pergunta realmente diferente pode ser dirigida ao intérprete, o leitor se coloca no limiar de experimentar algo novo e de enriquecer o seu horizonte com uma nova perspectiva sobre as coisas (CAPDEVILA Y CASTELIS, 2005, p. 320).

A história da recepção considera também a produção dos diversos gêneros do discurso como resultado dos efeitos, apropriação ou consumo de um texto. É o resultado concreto do caráter histórico da "reserva de sentido" do texto em sua forma dialógica. Dessa forma, a reconstrução hipotética de uma série de questões que os leitores fazem ao texto dentro de um horizonte histórico específico é um passo significativo para a história da recepção, pois estas questões podem, eventualmente, tornar-se um paradigma interpretativo e, para termos um quadro mais completo do efeito do texto nos leitores de um determinado período, seu horizonte de expectativa precisa ser reconstruído. Esta reconstrução ajuda a estabelecer vínculos entre as várias leituras históricas do texto, oferecendo uma perspectiva mais ampla do potencial e do efeito do texto, à medida que ele se desdobra em mundos de vida históricos. Os efeitos que o texto produz sobre os leitores podem ser compreendidos somente nas instâncias concretas dos atos de leitura de 
leitores históricos e de sua produção discursiva (MORALES VÁSQUEZ, 2012, p. 66-67).

A produção de discursos constitui as diversas manifestações culturais da recepção do texto. Por meio dos discursos, que podem ser qualquer produto ou expressão cultural concreta, desde documentos a instituições sociais, é possível reconstruir o diálogo travado em um determinado momento entre o texto e os leitores. Esses discursos tornam-se sinais e indicadores da direção que o diálogo assume. Culturalmente, eles sempre fazem a mediação de nosso acesso ao texto. A história da recepção de um texto destaca a interação entre texto e vida, ou seja, o mundo-vida dos leitores. Nesta interação, o texto pode contribuir na construção do mundo social dos leitores e, ao mesmo tempo, deixa claro o papel que seu mundo social desempenha no evento da compreensão. Os textos, como artefatos culturais, contribuem para a expansão dos mundos sociais de maneiras imprevistas por meio de sua interação com múltiplos leitores históricos. A leitura, a compreensão e a produção de texto e discurso são dependentes dessa relação. Os textos são compreendidos por meio de outros textos, que constituem suas interpretações e sua compreensão é determinado pelo mundo da vida dos seus receptores.

Como os comentários exegéticos representam um tipo de produção de discurso, o escopo de uma história da recepção envolve também a história da exegese bíblica. A história da exegese é parte da história da recepção, mas a recepção refere-se à atividade dos leitores que permite que o sentido do texto se desdobre historicamente. Esse desdobramento histórico deve ser entendido como um processo de comunicação, que gera uma tradição. Os leitores são responsáveis por estabelecer esse processo. A recepção destaca também o papel da tradição na compreensão. O fato de que os leitores pertencem a uma tradição não exclui a possibilidade de uma postura crítica. Acolher implica não só explicar o texto, mas também apropriá-lo e utilizá-lo. O leque de instâncias concretas de recepção representa diferentes formas de ler e se apropriar do texto, entre as quais a exegese é uma delas (MORALES VÁSQUEZ, 2012, p. 70-71).

A história da recepção não está preocupada com a reconstrução das etapas da produção de uma obra. Ela não procura determinar o significado do texto pretendido pelo autor, mas tem como objetivo demonstrar como o significado de um texto se desdobra historicamente. Por meio do confronto entre o horizonte de compreensão passado e o atual deixa-se claro como o significado do texto se desdobra historicamente pela interação entre efeito 
e recepção. A exegese procura explicar o texto e os comentários bíblicos oferecem leituras técnicas do texto. A teoria da recepção bíblica não iguala o texto à intenção autoral, não fala de uma exegese sem pressupostos, mas destaca o papel dos leitores que dialogam com o texto, manifestando a historicidade da compreensão das Escrituras. Ela não é monológica, mas dialógica, e reconhece os interesses presentes na perspectiva contemporânea dos leitores atuais que procuram compreender o passado. Com base nessas perspectivas de mudança no diálogo, o significado é historicamente constituído. O texto representa uma resposta às questões levantadas por seus primeiros leitores, mas gerações subsequentes de leitores podem levantar questões para as quais o texto não constitui uma resposta direta (MORALES VÁSQUEZ, 2012, 71-72).

A relação estabelecida entre a obra e o leitor é de ordem dialógica. Essa relação não é fixa, pois as leituras diferem a cada época e o leitor interage com a obra a partir de suas experiências anteriores, isto é, ele carrega consigo uma bagagem cultural de que não pode abrir mão e que interfere na recepção de uma criação literária particular. Todo ato de recepção, julgamento estético ou interpretação, por mais espontâneo que seja sua expressão, deriva de uma câmara de ecos onde ressoam os pressupostos históricos ou sociais que possibilitam sua efetivação. A compreensão de um texto requer o reconhecimento e a integração de suas várias dimensões. Para a história da recepção, um significante é entendido em sua vida histórica, ou seja, como uma enciclopédia ou como um léxico cultural. Essa rede semântica tem raízes históricas e se torna mais complexa a cada recepção pelas diversas gerações de leitores. Nesse sentido, o exame da diversidade de instâncias de recepção que as Escrituras produzem possibilita reconstituir as várias etapas do diálogo mantido entre o texto bíblico e seus leitores. Ao mesmo tempo, passamos também a compreender o surgimento das tradições que ampliam os horizontes das futuras gerações de leitores, juntamente com a compreensão do assunto ao qual o texto se refere. É no diálogo contínuo entre o texto e os seus leitores que acontece o desdobramento histórico do seu significado (MORALES VÁSQUEZ, 2012, p. 77-78).

\section{Conclusão}

Este artigo procurou demonstrar que a teoria da recepção representa um esforço interpretativo sobre a leitura e as relações estabelecidas entre texto, autor e leitor. A teoria da recepção não trata os signos textuais como 
obras acabadas, mas abertas a diversos olhares interpretativos, cujo sentido se consolida a partir do encontro entre o horizonte de expectativas dos autores e as possíveis significações estabelecidas pelos seus leitores. As materialidades significativas são entendidas como um complexo que tem sentido a partir da relação dialética instaurada entre o autor, a obra e seus possíveis leitores. Toda atividade interpretativa se constitui mediante o processo de interação entre a subjetividade do leitor e as condições sóciohistóricas na qual determinado signo se originou. Todo signo passível de leitura não se configura apenas como uma reprodução, reflexo dos eventos sociais que possibilitaram sua concepção, mas, antes, um constructo social e cultural que, a partir de sua historicidade, desempenha um papel ativo na produção das possíveis interpretações de cada leitor. O leitor é uma figura histórica que respeita a história do signo que lê, mas que ao mesmo tempo promove uma ruptura com as leituras feitas até aquele momento de leitura, empreendendo sua própria interpretação da obra que lhe é apresentada. As possibilidades de diálogo com a obra dependem do grau de identificação ou de distanciamento do leitor com ela, no que diz respeito às convenções sociais e culturais a que está vinculado e à consciência que delas possui. $\mathrm{O}$ leitor, como agente, precisa tornar o sentido do texto concreto. No caso dos textos bíblicos, o objeto dos estudos de recepção é a história da recepção, apropriação e impacto do texto bíblico na vida de seus leitores e leitoras. A teoria da recepção bíblica privilegia as condições de leitura do texto pelos seus leitores e leitoras, não a reconstrução de como a obra foi produzida, isto é, não procura determinar o significado original do texto pretendido pelo autor, mas demonstrar como o seu significado se desdobra historicamente.

\section{Referências}

ADRIANO FILHO, José. Estética da recepção e métodos histórico-críticos: o texto da perspectiva do leitor. Estudos Teológicos (São Leopoldo), v. 59, n. 2, p. 311-324, jul./dez. 2019.

BAKHTIN, Mikhail. Estética da Criação Verbal. São Paulo: Martins Fontes, 2003.

BORDini, M. G. \& AGUIAR, V. T. A formação do leitor. Alternativas Metodológicas. Porto Alegre: Mercado Aberto, 1988.

CAPDEVILA Y CASTELIS, Pol. Experiencia estética y hermenéutica. Un diálogo entre Immanuel Kant y Hans Robert Jauss. Tese de Doutorado. Universitat Autônoma de Barcelona, 2005.

COMPAGNON, A. O demônio da teoria. Literatura e senso comum. Belo Horizonte: Editora da UFMG, 2006. 
COSTA LIMA, Luiz. A literatura e o leitor. Textos de Estética da Recepção. 2. ed. Rio de Janeiro: Paz e Terra, 2002.

FISH, Stanley. Is there a text in this class? The Authority of Interpretative Communities. Cambridge, Mass.: Harvard University Press, 1980.

HOLUB, Robert C. Reception Theory. A critical introduction. London \& New York: METHUEN, 1984.

INGARDEN, Roman. A obra de arte literária. Lisboa: Fundação Calouste Gulbenkian, 1965.

JAUSS, Hans Robert. A história da literatura como provocação à ciência da literatura. [Trad. Sérgio Tellaroli de Literaturgeschichte als Provokation der Literaturwissenschaft. São Paulo: Ática, 1994.

JAUSS, Hans Robert. Aesthetic Experience and Literary Hermeneutics. Minneapolis: Universtity of Minnesota Press, 1982.

JAUSS, Hans Robert. Question and answer. Forms of Dialogic Understanding. Minneapolis: University of Minnessota Press, 1989.

MORALES VÁSQUEZ, Victor Manuel. Contours of a Biblical Reception Theory. Studies in the Rezeptionsgeschichte of Romans 13.1-7. Göttingen: V \& R Unipress, 2012.

NOGUEIRA, Paulo Augusto de Souza. "Religião como texto: contribuições da semiótica da cultura”. In: Linguagens da Religião. São Paulo: Paulus, 2012, p. 13-30.

PARRIS, David Paul. Reception Theory and Biblical Hermeneutics. Eugene, Oregon: PICKWICK Publications, 2009.

RÓDENAS DE MOYA, Domingos, "Hans Robert Jaus o el rescate de la historia desde la teoria”. In: JAUSS, Hans Robert. Historia de la literatura como provocación. Madrid: Editorial Gredos. S.A., 2013, p. 9-17.

STIERLE, Karlheinz. “¿Qué Significa “recepción” em los textos de ficción?” In: ANTONIO MAYORAL, José (coord.). Estetica de la recepción. Madrid, Arco Libros, 1987, p. 87-144. ZILBERMAN, Regina. Fim do livro, fim dos leitores? São Paulo: SENAC, 2001.

Submetido em: 13-8-2021

Aceito em:11-10-2021 